\title{
Performance studies on different okra varieties and hybrids under arid climatic conditions of Rajasthan
}

\section{MK Meena, SK Moond, Devkaran, M Meena \& S Khardu}

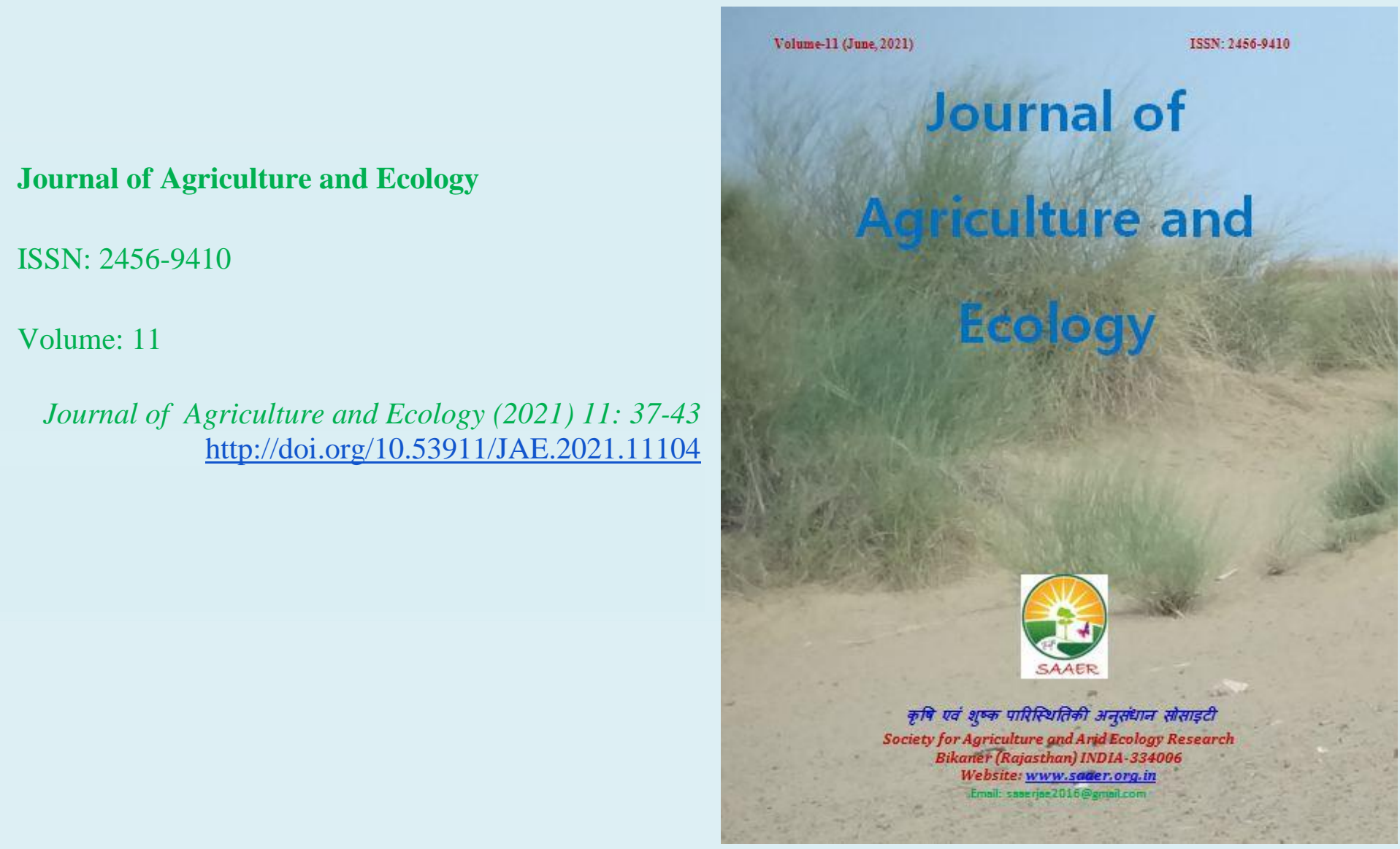




\title{
Performance studies on different okra varieties and hybrids under arid climatic conditions of Rajasthan
}

\author{
MK Meena $\varnothing$, SK Moond, Devkaran, M Meena \& S Khardu \\ Department of Horticulture, College of Agriculture (Agriculture University, Jodhpur), Jodhpur-342304 \\ (Rajasthan) \\ Corresponding author: MK Meena,E-mail: rgvmeena11@gmail.com
}

\section{Article Info}

Article history

Received: 01 June 2021

Accepted: 25 June 2021

Available online: 30 June 2021

\begin{abstract}
An experiment entitled "Performance and genetic variability studies in okra (Abelmoschus esculentus (L.) Moench)" was carried out during August 2019 to November 2019 at the Research farm, College of Agriculture, Jodhpur (Rajasthan). The experiment comprised of 12 varieties and hybrids of okra viz. 'P-8', 'Pusa Bhindi-5', 'Samrat $F_{1}$ Hybrid', 'Punjab Suhawani', 'Arka Nikita', 'Shakshi $F_{1}$ Hybrid', 'Palam Komal', 'Kashi Kranti', 'Shakti $\mathrm{F}_{1}$ Hybrid', 'Arka Anamika', 'Kashi Pragati' and 'Laxmi $\mathrm{F}_{1}$ Hybrid' and was laid out in Randomized Block Design with three replications. Significant differences were found amongst the varieties and hybrids of okra for the studied characters. The 'Arka Anamika' recorded the maximum number of branches per plant (2.80), stem diameter $(17.10 \mathrm{~mm})$, number of leaves per plant (69.06), number of fruit per plant (25.80), fruit yield per plant $(319.78 \mathrm{~g})$, fruit yield per plot $(4.95 \mathrm{~kg})$, estimated fruit yield per hectare $(122.30$ q). The 'Palam Komal' recorded the maximum plant height (139.73) and numbers of nodes on main stem (30.80). The 'Laxmi $F_{1}$ Hybrid' produced the largest leaves $\left(156.86 \mathrm{~cm}^{2}\right)$. The earliest first flower anthesis and 50\% flowering and first picking were noted in 'Kashi Pragati' (38.67, 39.33 and 45.40 DAS, respectively). The 'Pusa Bhindi-5' recorded the maximum fruit length $(12.36 \mathrm{~cm})$. The 'Samrat $\mathrm{F}_{1}$ Hybrid' recorded the maximum fruit diameter $(16.02 \mathrm{~mm})$ and fruit weight $(12.99 \mathrm{~g})$. The maximum shelf life of fruit was recorded in 'Kashi Kranti' (4.47 Days). Five ridges per fruit were exhibited in all the okra varieties and hybrids. From the present investigation it can be concluded that okra variety 'Arka Anamika' performed best for various growth and yield traits under arid climatic conditions of Rajasthan.
\end{abstract}

\footnotetext{
Copyright (C2021 Meena et al., This is an open access article published under the terms of the Creative Commons Attribution License, which permits unrestricted use, distribution, and reproduction in any medium, provided the original work is properly cited.

Preferred citation: Meena MK, Moond SK, Devkaran, Meena M \& Khardu S. 2021. Performance studies on different okra varieties and hybrids under arid climatic conditions of Rajasthan. Journal of Agriculture and Ecology, 11: 37-43; http://doi.org/10.53911/JAE.2021.11104.
}

\section{Introduction}

Okra [Abelmoschus esculentus (L.) Moench] is an important annual vegetable crop in tropical and subtropical regions of the world. It belongs to family Malvaceae with chromosome number $2 n=130$. Okra is also known as bhindi in Hindi and lady's finger in English. In Indian cooking, it is often fried or 
added to gravy-based preparations. Tender green fruits are used as fried vegetable or in curry, sambar and soups. Sun dried okra is used in Africa and India for year round consumption. Okra is rich source of iodine and good source of calcium $(66 \mathrm{mg} / 100 \mathrm{~g}$ fresh) and phosphorus (56 mg/100g fresh). Its tender fruits contain protein (1.9\%), carbohydrate $(6.4 \%)$, and fiber $(1.2 \%)$, and Vitamin A (88 IU), Thiamine (00.7 mg), Riboflavin $(0.10 \mathrm{mg}$ ) and Vitamin C (13 mg) per $100 \mathrm{~g}$ fresh edible portion. Dry seeds contain 20-24\% protein (Hazra and Som, 2006; Samadia \& Haldhar et al. 2019).

Okra is mainly grown in Afghanistan, India, Iran, Nigeria, Turkey, Ghana, Egypt, Brazil and Mexico. In India, okra shares 5.28 million hectare area and 61.46 million tonnes production with a productivity of 12.2 million tonnes per hectare (Anonymous, 2018). Maharashtra, Gujarat, Karnataka, Tamil Nadu, Haryana, Punjab, Uttar Pradesh, Bihar, West Bengal and Orissa are principal okra growing state in India. Rajasthan has 1.3 million hectare area under okra cultivation with production of 8.34 million tonnes and productivity of 5.15 MT per ha (Anonymous, 2018).

Okra is cultivated for domestic as well as export markets in India. High yielding varieties which are resistant to diseases (especially yellow vein mosaic virus) and pests are becoming farmers choice due to better quality produce with lower cost of crop protection. However, the new varieties and hybrids perform well under specific climatic conditions and poorly under some different climatic conditions. This leads to farmers reluctance towards the improved genotypes until and unless their performance under the given climatic conditions is proved. The yield of okra is primarily determined by length and thickness of the pods and the number of pods produced per plant. These factors are governed by genetic constitution of the plant. The stage of pod harvesting also contribute equally to the yield. Therefore, the stage of pod picking is very important as far as yield and quality of pods is concerned. For export purpose, fibreless tender dark-green thin pods of 5 to $7 \mathrm{~cm}$ length with less number of ridges and bristles are required. The okra pods are generally harvested at 2 to 4 days intervals (Meena \& Bhati 2016).

Production and productivity of okra seriously affected by the use of low yielding local varieties, plant population, weed infestation, insect-pest and diseases etc. Higher production of this crop is possible by the cultivation of varieties and hybrids which give high net returns, compared to other cultivars grown at same climatic conditions and inputs applied. However, productivity could be improved through careful evaluation and selection of proper okra varieties and hybrids based on location. Keeping these considerations in view, the present investigation was carried out with an objective to evaluate the growth, flowering and yield parameters of okra varieties and hybrids.

\section{Materials and Methods}

The field experiment was conducted at the Research farm, College of Agriculture, Jodhpur (Rajasthan) kharif season of 2019-20. Experimental material comprised 12 different varieties and hybrids of okra collected from different sources. Okra varieties and hybrids were evaluated in a randomized block design 
with three replications. Seed were sown at a spacing of $60 \mathrm{~cm}$ between row to row and 45 $\mathrm{cm}$ between plant to plant. Cultural practices and plant protection measures were followed as per the requirements. Observations were recorded on five competitive plants for 16 characters viz. plant height $(\mathrm{cm})$, number of branches per plant, number of nodes on main stem, number of leaves per plant, leaf area $\left(\mathrm{cm}^{2}\right)$, stem diameter $(\mathrm{mm})$, days taken to first anthesis, days taken to $50 \%$ flowering, days taken to first picking, fruit length $(\mathrm{cm})$, fruit diameter $(\mathrm{mm})$, fruit weight $(\mathrm{g})$, number of fruits per plant, fruit yield per plant $(\mathrm{g})$ and shelf life of fruit (Days).

\section{Result and Discussion}

Okra varieties and hybrids exhibit variability with respect to various growth, flowering and yield parameters (Table 1). The maximum plant height and nodes per plant were recorded in 'Palam Komal' (139.73 cm (30.80), respectively,) while the minimum in 'P-8' and 'Shakshi F $F_{1}$ Hybrid' $(117.40 \mathrm{~cm}$ and $21.13 \mathrm{~cm}$, respectively). The significant differences amongst the varieties and hybrids for plant height could be attributed to their genetic constitution and inheritance of the character as well as differences in apical dominance controlled by the endogenous auxin level of the genotypes. The obtained results are in accordance with earlier finding of Kandasamy et al. (2015), Darshan et al. (2016) and Deepanshu \& Shamad (2017).

The maximum numbers of branches per plant (2.80) and leaves per plant (69.06) were found in 'Arka Anamika' while the minimum numbers of branches per plant
(1.80) and leaves per plant (54.13) were found in 'Pusa Bhindi-5' and 'Punjab Suhawani', respectively. The differences amongst the varieties and hybrids for number of branches per plant could be attributed to their differential endogenous auxin and cytokinin contents which regulate the lateral growth and bud development, as low auxin and higher cytokinin levels promote lateral growth and bud development or vice-versa. The variation in number of leaves per plant may be due to varying branching in plants. The findings are in agreement with the results of Deepanshu \& Shamad (2017) and Kumar et al. (2019) for number of branches per plant and Kumar et al. (2016) for number of leaves per plant. The thickest stems were produced in 'Arka Anamika' $(17.10 \mathrm{~mm})$ while the thinnest in 'Pusa Bhindi-5' (13.08 mm). The differences in stem diameter of various genotypes may be due to influence of their genetic makeup regulating the endogenous hormone balance which control the cell division and cell enlargement resulting in differential branching which ultimate affect the stem girth. The present findings are supported by Kumar et al. (2016) and Singh et al. (2017). The largest leaves $\left(156.86 \mathrm{~cm}^{2}\right.$ area) were recorded in 'Laxmi $\mathrm{F}_{1}$ Hybrid' while the smallest leaves (115.81 $\mathrm{cm}^{2}$ area) in 'Kashi Pragati'. The variation in leaf area amongst the varieties and hybrids of okra might be due to their genetic makeup governing the nutrient uptake behaviour, photosynthetic efficiency and their environmental interactions. The observed results are in accordance to Chandramouli et al. (2016). 
Table 1. Performance of okra varieties and hybrids for various growth and flowering parameters

\begin{tabular}{|c|c|c|c|c|c|c|c|c|c|}
\hline $\begin{array}{l}\text { Treat } \\
\text { ment }\end{array}$ & Variety/Hybrid & $\begin{array}{c}\text { Plant } \\
\text { height } \\
(\mathrm{cm})\end{array}$ & $\begin{array}{c}\text { Number } \\
\text { of } \\
\text { branches } \\
\text { per plant }\end{array}$ & $\begin{array}{c}\text { Stem } \\
\text { diameter } \\
(\mathbf{m m})\end{array}$ & $\begin{array}{c}\text { Number } \\
\text { of nodes } \\
\text { on main } \\
\text { stem }\end{array}$ & $\begin{array}{c}\text { Number } \\
\text { of leaves } \\
\text { per } \\
\text { plant }\end{array}$ & $\begin{array}{l}\text { Leaf } \\
\text { area } \\
\left(\mathrm{cm}^{2}\right)\end{array}$ & $\begin{array}{c}\text { Days } \\
\text { taken to } \\
\text { first } \\
\text { anthesis }\end{array}$ & $\begin{array}{c}\text { Days } \\
\text { taken to } \\
50 \% \\
\text { flowering }\end{array}$ \\
\hline $\mathrm{T}_{1}$ & $\mathrm{P}-8$ & 117.40 & 2.07 & 14.06 & 23.13 & 60.60 & 132.21 & 41.20 & 42.33 \\
\hline $\mathrm{T}_{2}$ & Pusa Bhindi-5 & 126.17 & 1.80 & 13.08 & 24.67 & 62.67 & 119.51 & 48.60 & 51.00 \\
\hline $\mathrm{T}_{3}$ & Samrat $F_{1}$ Hybrid & 127.73 & 2.40 & 16.26 & 29.87 & 64.73 & 135.22 & 42.87 & 43.67 \\
\hline $\mathrm{T}_{4}$ & Punjab Suhawani & 121.13 & 1.87 & 13.23 & 26.07 & 54.13 & 139.60 & 45.73 & 48.33 \\
\hline $\mathrm{T}_{5}$ & Arka Nikita & 127.13 & 2.20 & 14.63 & 27.67 & 61.20 & 151.28 & 40.40 & 41.33 \\
\hline $\mathrm{T}_{6}$ & Shakshi $F_{1}$ Hybrid & 117.20 & 2.33 & 15.40 & 21.13 & 62.53 & 149.69 & 42.53 & 44.33 \\
\hline $\mathrm{T}_{7}$ & Palam Komal & 139.73 & 2.13 & 13.75 & 30.80 & 68.33 & 145.40 & 44.60 & 46.33 \\
\hline $\mathrm{T}_{8}$ & Kashi Kranti & 120.00 & 2.07 & 13.15 & 23.20 & 56.80 & 119.46 & 40.93 & 42.00 \\
\hline $\mathrm{T}_{9}$ & Shakti $F_{1}$ Hybrid & 124.07 & 2.33 & 15.39 & 28.20 & 65.13 & 148.06 & 45.80 & 47.33 \\
\hline $\mathrm{T}_{10}$ & Arka Anamika & 136.07 & 2.80 & 17.10 & 30.20 & 69.06 & 143.72 & 46.60 & 47.67 \\
\hline $\mathrm{T}_{11}$ & Kashi Pragati & 125.47 & 2.20 & 14.17 & 26.67 & 61.53 & 115.81 & 38.67 & 39.33 \\
\hline $\mathrm{T}_{12}$ & Laxmi $F_{1}$ Hybrid & 118.53 & 2.27 & 15.30 & 21.40 & 58.60 & 156.86 & 45.47 & 46.00 \\
\hline \multicolumn{2}{|c|}{ SEm $( \pm)$} & 3.88 & 0.13 & 0.39 & 1.70 & 2.38 & 3.44 & 0.81 & 1.25 \\
\hline \multicolumn{2}{|c|}{$\mathrm{CD}(\mathrm{P}=0.05)$} & 11.38 & 0.38 & 1.17 & 4.99 & 7.00 & 10.10 & 2.38 & 3.68 \\
\hline \multicolumn{2}{|c|}{$\mathrm{CV}(\%)$} & 5.37 & 10.40 & 4.72 & 11.30 & 6.66 & 4.32 & 3.22 & 4.84 \\
\hline
\end{tabular}

The earliest flower anthesis and 50\% flowering were recorded in 'Kashi Pragati' (38.67 DAS and 39.33 DAS, respectively), while the most late flower anthesis and $50 \%$ flowering were recorded in 'Pusa Bhindi-5' (48.60 DAS and 51.00 DAS, respectively). The early or late production of flowers by different varieties and hybrids of okra might have been genetically controlled and better adaptability to particular environmental conditions as supported by the earlier findings of Kandasamy et al. (2015) and Kumar et al. (2017). The earliest fruit picking was recorded in 'Kashi Kranti' (45.40 DAS), while the late picking was recorded in 'Pusa Bhindi-5' (54.73 DAS). The early or late bearing in different okra varieties and hybrids could be attributed to their differential genetic makeup and environmental interaction, as supported by the earlier findings of Chandramouli et al. (2016) and Kumar et al. (2017). The maximum fruit length at marketable stage was found in 'Pusa Bhindi-5' $(12.36 \mathrm{~cm})$ while the minimum $(10.35 \mathrm{~cm})$ in 'Laxmi $F_{1}$ Hybrid'. The significant differences for fruit length in the varieties and hybrids may be due to their genetic makeup leading to differential synthesis, translocation and accumulation of photosynthates in the sink (fruit). Similar results have been reported by Chandramouli et al. (2016), Kumar et al. (2017) and Rajesh et al. (2018).

The thickest fruits $(16.02 \mathrm{~mm}$ diameter) were recorded in 'Samrat $F_{1}$ Hybrid', while the thinnest $(13.45 \mathrm{~mm})$ in 'Laxmi $F_{1}$ Hybrid'. The fruit size (length and diameter) of okra at marketable maturity stage is an important varietal characteristic that is primarily governed by its genotypic constitution and secondarily by availability of water and nutrients coupled with influence of the growing climate. The differences obtained 
in fruit diameter amongst the varieties and hybrids of okra could be attributed to their genetic makeup and the prevailing environmental factors (Table 2). Similar results have been reported by Akotkar et al. (2010) and Chandra et al. (2014). The maximum fruit weight at marketable maturity stage was recorded in 'Samrat $F_{1}$ Hybrid' $(12.99 \mathrm{~g})$, while the minimum fruit weight in 'Laxmi $F_{1}$ Hybrid' (10.39 g). The observed variation in fruit weight amongst the varieties and hybrids of okra might be due to their genetic makeup governing the fruit size and sink-source relationship in diversion of photosynthates to the fruit. The results find support from Deepanshu \& Shamad (2017) and Kumar et al. (2017).

The maximum number of fruits per plant and fruit yield per plant were recorded in 'Arka Anamika' (25.80 and $319.78 \mathrm{~g}$, respectively), while the minimum number of fruits per plant and fruit yield per plant were recorded in 'Shakshi $F_{1}$ Hybrid' and 'Laxmi $\mathrm{F}_{1}$ Hybrid' (18.67 and $195.25 \mathrm{~g}$, respectively). The number of fruits and yield per plant had high positively genotypic and phenotypic correlation with high number of branches per plant with more number of nodes on the plant, providing the site for fruit production. The observed variation in number of fruits and fruit yield per plant amongst the varieties and

Table 2. Performance of okra varieties and hybrids for various yield parameters

\begin{tabular}{|c|c|c|c|c|c|c|c|c|c|}
\hline Treatment & Variety/Hybrid & $\begin{array}{c}\text { Days } \\
\text { taken to } \\
\text { first } \\
\text { picking }\end{array}$ & $\begin{array}{l}\text { Fruit } \\
\text { length } \\
\text { (cm) }\end{array}$ & $\begin{array}{l}\text { Fruit } \\
\text { diameter } \\
(\mathbf{m m})\end{array}$ & $\begin{array}{c}\text { Fruit } \\
\text { weight } \\
\text { (g) }\end{array}$ & $\begin{array}{l}\text { Number } \\
\text { of fruit } \\
\text { per } \\
\text { plant }\end{array}$ & $\begin{array}{l}\text { Fruit } \\
\text { yield } \\
\text { per } \\
\text { plant } \\
\text { (g) }\end{array}$ & $\begin{array}{c}\text { Fruit } \\
\text { yield } \\
\text { per ha } \\
\text { (qt.) }\end{array}$ & $\begin{array}{c}\text { Shelf } \\
\text { life } \\
\text { (days) }\end{array}$ \\
\hline $\mathrm{T}_{1}$ & $\mathrm{r}-\mathrm{O}$ & 47.40 & 11.49 & 14.51 & 11.08 & 21.07 & 224.09 & 77.78 & 4.13 \\
\hline $\mathrm{T}_{2}$ & Pusa Bhindi-5 & 54.73 & 12.36 & 14.09 & 11.44 & 20.60 & 229.34 & 92.51 & 4.13 \\
\hline
\end{tabular}
makeup governing the number and size of fruits due to varying and sink-source relationships. The present findings are in accordance with Kandasamy et al. (2015), Kumar et al. (2017) and Chandramouli et al. (2018). The highest estimated fruit yield per hectare $(122.30$ q) was recorded in 'Arka Anamika' whereas the minimum in 'Laxmi $F_{1}$ Hybrid' (70.37 q). It is evident from the results that number of fruits produced per plant and fruit yield per plant had directly influenced the fruit yield per unit area which had high positive correlation with fruit yield per plant for genotypic as well as phenotypic correlation. Similar results have been reported by Chandra et al. (2014), Deepanshu and Shamad (2017) and Chandramouli et al. (2018). The fruit qualitative parameters viz. fruit colour and fruit surface were noted and presented as their genetic qualitative traits. These characters were studied as qualitative traits of the varieties and hybrids of okra and were not subjected to statistical analysis.

The longest shelf life of fruit was recorded in 'Kashi Kranti' (4.47 days) while the shortest shelf life of fruit in 'Palam Komal' (3.33 days). The observed shelf life of fruit amongst the varieties and hybrids of okra might be due to their genetic makeup and storage conditions 


\begin{tabular}{|c|c|c|c|c|c|c|c|c|c|}
\hline $\mathrm{T}_{3}$ & $\begin{array}{l}\text { Samrat } F_{1} \\
\text { Hybrid }\end{array}$ & 49.33 & 11.93 & 16.02 & 12.99 & 23.00 & 285.86 & 116.13 & 3.40 \\
\hline $\mathrm{T}_{4}$ & $\begin{array}{l}\text { Punjab } \\
\text { Suhawani }\end{array}$ & 53.93 & 11.57 & 15.49 & 12.50 & 20.73 & 249.30 & 86.42 & 3.73 \\
\hline $\mathrm{T}_{5}$ & Arka Nikita & 47.33 & 10.65 & 14.21 & 10.93 & 21.27 & 221.28 & 81.32 & 4.00 \\
\hline $\mathrm{T}_{6}$ & $\begin{array}{l}\text { Shakshi } F_{1} \\
\text { Hybrid }\end{array}$ & 48.47 & 11.04 & 15.54 & 11.33 & 18.67 & 206.21 & 78.52 & 4.47 \\
\hline $\mathrm{T}_{7}$ & Palam Komal & 51.20 & 10.94 & 14.26 & 11.07 & 23.73 & 254.53 & 93.09 & 3.33 \\
\hline $\mathrm{T}_{8}$ & Kashi Kranti & 47.47 & 11.07 & 14.93 & 11.25 & 19.07 & 210.62 & 91.36 & 4.47 \\
\hline $\mathrm{T}_{9}$ & $\begin{array}{l}\text { Shakti } F_{1} \\
\text { Hybrid }\end{array}$ & 52.06 & 11.64 & 15.70 & 12.63 & 22.73 & 273.18 & 96.38 & 4.33 \\
\hline $\mathrm{T}_{10}$ & Arka Anamika & 53.53 & 12.01 & 14.86 & 12.53 & 25.80 & 319.78 & 122.30 & 4.27 \\
\hline $\mathrm{T}_{11}$ & Kashi Pragati & 45.40 & 11.97 & 14.25 & 11.51 & 21.87 & 243.65 & 99.09 & 4.07 \\
\hline $\mathrm{T}_{12}$ & $\begin{array}{l}\text { Laxmi } F_{1} \\
\text { Hybrid }\end{array}$ & 52.06 & 10.35 & 13.45 & 10.39 & 20.20 & 195.25 & 70.37 & 3.60 \\
\hline $\operatorname{SEm}( \pm)$ & & 1.07 & 0.34 & 0.43 & 0.36 & 0.80 & 13.37 & 4.20 & 0.14 \\
\hline $\mathrm{CD}(\mathrm{P}=0.05$ & & 3.15 & 1.02 & 1.28 & 1.07 & 2.36 & 39.21 & 12.30 & 0.42 \\
\hline CV (\%) & & 3.70 & 5.28 & 5.11 & 5.46 & 6.46 & 9.54 & 7.90 & 6.24 \\
\hline
\end{tabular}

\section{Conclusion}

On the basis of experimental findings of the overall performance of okra varieties and hybrids, it was be concluded that amongst all the varieties and hybrids 'Arka Anamika' was found best performer under arid climatic conditions of western Rajasthan with the maximum number of branches per plant (2.80), stem diameter $(17.10 \mathrm{~mm})$, number of leaves per plant (69.06), number of fruit per plant (25.80), fruit yield per plant (319.78 g), fruit yield per plot $(4.95 \mathrm{~kg})$, estimated fruit yield per hectare (122.30 q).

\section{References}

Akotkar PK, De DK \& Pal AK. 2010.Genetic variability and diversity in okra [Abelmoschus esculentus (L.) Moench]. Electronic Journal of Plant Breeding, 1(4): 393-398.
Anonymous. 2018. Horticulture Statistics at a Glance. Ministry of Agriculture and Farmers Welfare (Department of Agriculture, Cooperation and Farmers Welfare) Krishi Bhawan, New Delhi.

Chandra S, Bhardwaj ML, Kumar R, Kumar D, Kumar S, Gautam N, Dogra B \& Sharma, S. 2014. Estimation of parameters of variability for different quantitative traits in okra [Abelmoschus esculentus (L.) Moench]. International Journal of Farm Sciences, 4(3): 33-41.

Chandramouli B, Shrihari Rao ABDD \& Rao MP. 2016.Studies on genetic variability, heritability and genetic advance in okra [Abelmoschus esculentus (L.) Moench] genotypes. Plant Archives, 16(2): 679682.

Darshan S, Nikitha J \& Arya K.2016. Genetic variability studies for yield and yield 
parameters in okra [Abelmoschus esculentus (L.) Moench]. Advances in Life Sciences, 5(17): 2278-3849.

Deepanshu \& Shamad A. 2017. Genetic variability, heritability and correlation coefficient in okra [Abelmoschus esculentus (L.) Moench]. in Allahabad agro climatic conditions. Plant Archives, 17(2): 1597-1602

Kumar A, Kumar S \& Maji S. 2016. Genetic variability, heritability and genetic advance studies in okra [Abelmoschus esculentus (L.) Moench]. International Journal of Agriculture Sciences, 8(57): 3122-3124.

Kumar A, Kumar R, Kumar A, Tyagi S, Solankey SS, Roy C and Verma RB. 2017. Studies on the performance and morphological characterization of okra [Abelmoschus esculentus (L.) Moench] Genotypes for yield and yellow vein mosaic viruses. International Journal of Current Microbiology and Applied Sciences, 6(7): 1102-1106.

Kumar A, Kumar M, Sharma VR, Singh MK, Singh B \& Chand P. 2019. Genetic variability, heritability and genetic advance studies in genotypes of okra [Abelmoschus esculentus (L.) Moench].
Journal of Pharmacognosy and Phytochemistry, 8(1): 1285-1290.

Meena NK \& Bhati A. 2016. Response of Nitrogen, phosphorous and potassium levels on gowth and yield of okra [Abelmoschus esculentus (L.) Moench.]. Journal of Agriculture and Ecology, 2: 17-24.

Rajesh J, PrasadVM \& Banothu LN. 2018. Evaluation of okra [Abelmoschus esculentus (L.) Moench] hybrids for growth parameters under Allahabad agro climatic condition. Journal of Pharmacognosy and Phytochemistry, 7(6): 1813-1816.

Samadia DK \& Haldhar SM. 2019. Scope and strategies for genetic improvement in vegetable crop-plants under high temperature and abiotic stressed climate of Rajasthan: A gap analysis. Journal of Agriculture and Ecology, 8: 1-18.

Singh HK, Singh KM \& Meraj Md. 2017. Growth and yield performance of okra [Abelmoschus esculentus (L.) Moench] varieties on farmer's field. International Journal of Current Microbiology and Applied Sciences, 7: 1411-1417. 